\title{
Review
}

\section{On small war: Carl von Clausewitz and people's war}

\author{
Sibylle Scheipers \\ Oxford University Press, Oxford, 2018, viii + 174pp., \\ ISBN: 978-0-19-879904-7
}

Contemporary Political Theory (2020) 19, S86-S89. https://doi.org/10.1057/s41296018-0272-x; published online 25 October 2018

A growing group of scholars is challenging the widespread view that Carl von Clausewitz was primarily a theorist of major interstate war. Drawing on his early works written during the Napoleonic Wars, in particular his writings on what today would be referred to as small-unit operations and partisan, or guerilla warfare, Christopher Daase, Beatrice Heuser, Martin Rink, and others have identified previously unrecognized continuities in Clausewitz's thinking, which extend from his analyses of 'small war' to his posthumously published magnum opus, On War. In her volume, Sibylle Scheipers adds important intellectual, socio-political and historical context to our understanding of the continuities and evolution in Clausewitz's thinking about warfare. Surveying recent analyses of Clausewitz's earlier works, Scheipers argues that the emerging scholarship thus far has failed to address how Clausewitz's thoughts about small war fed into his theory of war more generally (p. 13). Moreover, she takes aim at an older generation of Clausewitz scholars who variously doubted Clausewitz's familiarity with important intellectual debates of his time (pp. 14-18), anachronistically characterized his work as falling within the 'realist' school of International Relations theory (pp. 89-91; 106-107), and tended to read his work through the lens of the Cold War nuclear standoff ( $\mathrm{p}$. 147). The results have been problematic: an over-emphasis of Clausewitz's efforts to tame the subject of war through rational analysis, an impoverished conception of what Clausewitz meant by the term Politik and the erroneous conclusion that Clausewitz exclusively regarded war as instrumental and properly subordinate to state policy. Not all of these arguments are new (Daase and Davis, 2015, pp. 1-18). Nonetheless, Scheipers provides the most thorough attempt to link Clausewitz's intellectual biography to the history of ideas and, in doing so, she provides further grounds to conclude that much of what is believed about Clausewitz's thinking on the subject of warfare is wrong.

Scheipers makes her most original contribution in chapters two and three. Here she places Clausewitz's early writings on small war, including the 'Lectures on

(C) 2018 Springer Nature Limited. 1470-8914 Contemporary Political Theory Vol. 19, S1, S86-S89 www.palgrave.com/journals 
Small War' held at the Prussian War College from 1810 to 1811 , and his Testimonial (Bekenntnisdenkschrift) of 1812 - a general popular call to arms in support of national liberation - in the context of the intellectual debates taking place at the time. On the one side were German adherents to Enlightenment beliefs in the possibility of historical progress through the application of reason. On the other were the romantics and idealists, who criticized the Enlightenment conception of reason as restricting of the 'spirit' (Geist) and the concomitant free play of emotions and creativity. Anyone who is able to access Clausewitz in the original German immediately recognizes a style of thinking and writing that reminds one of contemporaries such as Immanuel Kant, a fact that led many to conclude that Clausewitz was in some fundamental sense Kantian. However, Scheipers persuasively argues that Clausewitz rejected what he regarded to be overly optimistic Kantian notions of progress, such as those found in the essay 'Toward Perpetual Peace' (1795). Drawing insight, and at times inspiration, from a broader range of German idealist and romantic authors - including Fichte, Schelling, Hegel, Schiller, but also Novalis - many of whom he probably knew (pp. 61-67), Clausewitz rejected a conception of human beings that emphasized reason at the neglect of passion. Efforts to model warfare with mathematical precision were thus doomed to failure. Instead, his approach to analysis, theorizing, and indeed strategy, stressed the need to bring both aspects of human nature into harmony (pp. 77-81).

The rhetorical and analytic device employed by Clausewitz in the 'Testimonial' rests on this duality. In the first of his three confessions, he allowed himself 'to speak from the heart and to express in the language of emotions what is and should be a matter of emotion' (Daase and Davis, 2015, p. 174). In the second, he endeavors 'to speak in the language of calm deliberation.... and thereby demonstrate that emotional people are not incapable of calm deliberation...' (Daase and Davis, 2015, p. 174). Anchoring Clausewitz's arguments in the broader intellectual debates amongst idealists, romantics, and humanists, Scheipers provides the best argument yet that the discussion of the people's militias, the Landwehr and Landsturm - developed in the third confession - represents the synthesis or sublation of the dialectic created by the emotional and rational arguments of the first two (p. 79).

From the perspective of the humanistic ideal of balance between reason and passion, the 'trinitarian' conception of war Clausewitz developed in On War emerges not as a 'tripartite structure, but rather a dichotomous one' (p. 118). The notion of the 'free play of the spirit' - rationalist in its original articulation by Lessing but reformulated by Schiller to incorporate emotions - unifies (or sublates) the primordial emotions of 'hatred and enmity' on the one side, and 'pure reason' on the other, in Clausewitz's triangle (pp. 113, 118). Scheipers achieves these insights by adopting a middle ground of her own, a methodological position between post-structuralism and the sort of contextualism advocated by Quentin

(C) 2018 Springer Nature Limited. 1470-8914 Contemporary Political Theory $\quad$ Vol. 19, S1, S86-S89 $\quad$ S87 
Skinner. Without offering a judgement on the persuasiveness of her own methodological commitments, Scheipers does succeed in demonstrating not only an epistemological but also a theoretical and conceptual continuity between Clausewitz's engagement with idealist and romantic thought in the period of Napoleonic occupation, when he was actively agitating for Prussian military reform, and his later efforts to develop a general theory of war.

Though I agree with her argument that there was no clear rupture in Clausewitz's political thought after 1815 (p. 99), I am not persuaded by her claims regarding the process whereby early small war ideas were integrated into $O n$ War. The argument is too nuanced and elaborate to summarize here, but Scheipers's basic claim is that Clausewitz's thinking on people's war, especially as it relates to his arguments about the superiority of defense over offense, changed over time. She regards his thinking prior to 1826-1827 to be 'unclear and fuzzy' (p. 134). He could only see the political implications of the shift in warfare brought about by the levée en masse (p. 134) with the passing of time. Clausewitz's early thinking about the superiority of the defense is characterized as 'largely aspirational' (p. 128) and his thoughts on how the offense leads to fatigue (Ermüding), tautological (p. 130). Only after reflecting on the subsequent course of the war and Napoleon's eventual defeat was Clausewitz able to understand that people's war would make the translation of battlefield victory into political gains all but impossible, a fact that, once understood, would contribute to stability and the maintenance of the status quo via the logic of conventional deterrence or deterrence by denial (pp. 130-137).

In fact, however, Clausewitz already points to such a relationship when writing the 'Testimonial' in 1812. After discussing the advantages of active defenses over the strategic offense, he concludes: 'The war of the current era is a war of all against all. Kings no longer wage war against kings, nor armies against each other, but one nation against the other, the nation encompassing the king and army' (Daase and Davis, 2015, p. 216). Paradoxically, the very success of the levée en masse in Spain and France would render it unnecessary in the future. Once the nation-state had come to dominate Europe, Clausewitz believed that the 'boring chess-game of struggling soldiers' would become a thing of the past, while the shared knowledge that armed conflicts could escalate to people's war would serve as a potent deterrent (Daase and Davis, 2015, p. 216).

If anything, the continuities between Clausewitz's earlier writings on small war and the general theory developed in On War are even stronger than Scheipers admits, an argument the reader can probe by consulting either the original German texts in the Werner Hahlweg volumes Scheipers references, or the recently published English language translations (Daase and Davis, 2015).

Scheipers doubts that Clausewitz's writings on small war will be of much use to those engaged in small war today (p. 150). But even if Clausewitz does not provide any simple lessons, American policy-makers certainly would have benefited from a 
better understanding of the political implications of people's war, the advantages of active defenses, and the ways in which small war actually can constitute a people (p. 83) and thereby arouse passions that make foreign control unlikely, if not impossible. Even a superficial look at the aftermath of American interventions in Afghanistan and Iraq suggests that Scheipers's understanding of Clausewitz's most famous dictum is right. People's war is not merely a form of instrumental state policy; rather, it is politics by other means.

\section{Reference}

Daase, C. and Davis, J. (Eds. and Trans.) (2015). Clausewitz on small war. Oxford: Oxford University Press.

James W. Davis

University of St. Gallen, CH-9000 St. Gallen, Switzerland james.davis@unisg.ch 